\title{
Menguatkan Akar Filosofis BUMN dalam Arus Industrialisasi: Kritik Terhadap Basis Pemikiran Era Revolusi Industri
}

\author{
Achmad Yunus \\ Sinergi BUMN Institue \\ yunusachmad.84@gmail.com
}

DOI : 10.23917/jjr.v9i1.8092

\section{Submission \\ Track:}

Received:

1 Mei 2019

Final Revision:

15 Juni 2019

Available online:

30 Juni 2019

Corresponding

Author:

Achmad Yunus

yunusachmad.84@gmail.com

\section{ABSTRACT}

Tujuan: Artikel ini bertujuan untuk (1) mengelaborasi peran BUMN dalam era industrialisasi dunia yang cenderung dipersiapkan untuk berlayar pada kolam kapitalisme, dan (2) mengkomparasi realitas yang terjadi dengan prinsip dasar Indonesia sebagai negara Ketuhanan, dengan ancaman deferensiasi nilai, pemisahan agama dalam nilai-nilai kehidupan termasuk dalam dunia industry.

Metodologi: Penulisan ini menggunakan dua pendekatan, yaitu pendekatan perbandingan dan pendekatan sejarah. Pendekatan perbandingan dilakukan dengan membandingkan konsep kesejahteraan dengan negara lain. Sementara Pendekatan historis dilakukan untuk mengkaji sejarah-sejarah BUMN di setiap era pemerintahan.

Temuan: Hegemoni industrialisasi dunia yang dipropaganda masuk pada seri terbarunya yaitu 4.0 berdampak pada ancaman lunturnya nilai-nilai ideologis, padahal industrialisasi barat berpangkal pada filsafat modern dengan pragmatisme yang tinggi. Dampaknya adalah terbangunnya sistem industri yang cenderung barbar, miskin maslahat hanya berorientasi pada pemusatan kekuatan ekonomi oleh beberapa kelompok orang saja.

Kegunaan: BUMN harus membawa nilai-nilai nasional dalam kontestasi internasional, sehinga akan menjadi soko guru ekonomi bangsa dengan pemaksimalan pengelolaan sumber daya nasional yang dikelola dengan profesional, efektif, efisien, akuntabel, transparan dan mengedepankan kepentingan nasional.

Kebaruan/Orisinalitas: Menguatkan akar filosofis BUMN dalam arus industrialisasi adalah dengan tetap memegang tegun falsafah ekonomi Pancasila yang berorientasi pada kesejahteraan kolektif, tidak liberal, tidak sosialis dan bersendikan nilai-nilai Ketuhanan yang mengutamakan tingkat maslahat (kemanfaatan) dan nilai berkah (kebaikan yang terus-menerus dan berkesinambungan), sehingga kesenjangan ekonomi, sosial akan terkikis, keadilan dan kemakmuran menjadi nyata.

Keywords: BUMN, Industrialisasi, Revolusi Industri 


\section{PENDAHULUAN}

Revolusi industri adalah dampak dari perubahan perilaku manusia. Perubahan terjadi akibat keadaan yang bergerak. Dunia ini tidak statis tapi terdiri dari kehidupan-kehidupan yang saling menyapa, dinamis dan penuh pergerakan, mulai pergerakan terkecil dalam tubuh mahluk hidup hingga pergerakan massal. Pergerakan terkecil dalam tubuh manusia menjadi indikator manusia itu hidup, berhenti bergerak menandakan tubuh kita mati. Disadari atau tidak komponen tubuh kita bergerak selama 24 jam, bahkan saat manusia tidur pun jantung tetap memompa darah ke seluruh penjuru tubuh, ketika jantung berhenti memompa maka itulah kematian manusia.

Perubahan perilaku manusia merupakan penyebab dari perubahan-perubahan yang terjadi dalam struktur kehidupan sosial manusia, termasuk revolusi industri. Gelombang perubahan demi perubahan tersebut semakin menitikberatkan pada waktu sebagai indikatornya. Penggunaan waktu adalah indikator kemajuan sebuah peradaban, hal itu sebenarnya telah disampaikan Allah SWT pada tahun 570-an Masehi dengan diturunkannya Surat Al Ashr. Surat ini cukup singkat, hanya terdiri dari 6 ayat tetapi memiliki makna yang sangat dalam, bahkan saking mendalamnya Imam Syafii mengatakan andai Al-Quran tidak ada, maka Surat Al Ashr saja sudah cukup menjadi pedoman manusia untuk mencegah datangnya kerugian demi kerugian.

Imam Al-Gazhali menggambarkan bagaimana pentingnya kita memanfaatkan waktu. Andai rata-rata umur manusia 60 tahun, sementara dalam sehari manusia butuh tidur minimal 8 jam, maka seumur hidup manusia butuh 20 tahun hanya sekedar untuk tidur saja, sementara kita harus membagi waktu untuk kegiatan selain tidur seperti makan, bermain, bekerja, belajar, ibadah dll. Oleh karena itu penggunaan waktu dengan optimal menjadi kunci kesuksesan manusia di dunia dan akherat ${ }^{1}$. Perubahan waktu mengakibatkan terjadinya pergerakan-pergerakan. Pergerakan secara massal mengakibatkan perubahan yang juga massif, bahkan menandai sebuah peradaban kehidupan manusia. Katakanlah terjadinya revolusi industri, disebabkan karena manusia mengalami perubahan akibat pergerakanpergerakan secara massal dalam melakukan proses produksi. Revolusi Industri adalah ikon perubahan, penanda perubahan keadaan dan peradaban. Revolusi industri 1.0 (akhir tahun

\footnotetext{
${ }^{1} \mathrm{KH}$. Abdullah Gymnastiar menyebutkan bahwa disiplin (penggunaan waktu) bukan hanya ilmu milik militer saja, tapi ilmu bagi seluruh manusia. Tiada prestasi tanpa disiplin bahkan tiada surga tanpa disiplin, karena ibadah Sholat ditentukan dengan batas-batas waktu maupun gerakan pengerjaannya.
} 
1800-an) melahirkan sejarah ketika tenaga manusia dan hewan digantikan oleh mesin, salah satunya munculnya mesin uap di abad 18. Perubahan ini dicatat oleh sejarah berhasil meningkatkan rata-rata pendapatan negara per kapita hingga 6 kali lipat. Revolusi Industri 2.0 (tahun 1870-an) disebabkan karena pesatnya industrialisasi di akhir abad ke-19 yang menekankan pada revolusi teknologi yang ditandai dengan lahirnya pembangkit tenaga listrik dan motor pembakaran dalam (combustionchamber) yang memicu kemunculan pesawat telpon, mobil, pesawat terbang dan mengubah wajah dunia dengan signifikan.

Revolusi industri 3.0 ditandai dengan kemunculan penggunaan elektronik dan teknologi informasi guna otomatisasi produksi dan teknologi digital, Revolusi industri 3.0 mengubah pola relasi dan komunikasi masyarakat kontemporer. Dunia kembali dipaksa untuk melakukan perubahan, termasuk dalam proses bisnis agar tidak tertelan zaman, revolusi industri ketiga ini ditandai salah satunya dengan munculnya pengontrol logika terpogram pertama (PLC) yakni modem 084-969, Sistem otomatisasi berbasis komputer ini membuat mesin industri tidak lagi dikendalikan oleh manusia. Perubahan ini bukan tidak memakan tumbal, teknologi membuat pabrik-pabrik dan mesin industri lebih memilih mesin daripada tenaga manusia, apalagi mesin canggih, inilah perubahan manusia yang mengancam eksistensi manusia itu sendiri.

Saat ini kita tengah terseret dalam pusaran arus revolusi industri yang dipropaganda sedemikian rupa hingga era industri 4.0. Jika kita amati, waktu jeda dengan era industri 3.0 memang cukup singkat ${ }^{2}$, artinya perubahan manusia kini lebih cepat dibanding sebelumnya. Era industri 4.0 ditandai dengan sistem cyber-physical. Industri mulai merambah dunia virtual, tiga ciri dalam revolusi industri 4.0 adalah robotic, konektivitas manusia, mesin dan data (internet of things) serta kecerdasan tambahan (artificial intelligence), fase ini menandai perubahan yang tidak kalah signifikan yaitu pemampatan ruang dan waktu yang dulunya berjarak menjadi tidak berjarak (menyatukan), era digital mengusung sisi kekinian (real time). Era ini sangat revolusioner, hingga Presiden pun membaca peluang dan tantangan ini dengan membuat roadmap dengan nama Making Indonesia 4.0.

\footnotetext{
${ }^{2}$ Era industri 1.0 (1784) menuju 2.0 (1870) membutuhkan waktu 86 tahun, dari 2.0 menuju 3.0 (1970) membutuhkan waktu 100 tahun, dari 3.0 menuju 4.0 (2015) membutuhkan waktu 45 tahun
} 


\section{METODOLOGI PENELITIAN}

Penelitian ini menggunakan dua pendekatan dalam menjawab permasalahan, yaitu pendekatan perbandingan dan pendekatan sejarah. Pendekatan perbandingan merupakan salah satu cara yang digunakan dalam penelitian normatif untuk membandingkan salah satu lembaga hukum (legal istitutions) dari sistem hukum yang satu dengan lembaga hukum (yang kurang lebih sama dari sistem hukum) yang lain. Dari perbandingan tersebut dapat ditemukan unsur-unsur persamaan dan perbedaan kedua sistem hukum itu. Pendekatan sejarah dilakukan karena Hukum pada masa kini dan hukum pada masa yang lampau saling berhubungan sebagai satu kesatuan yang tidak putus. Sehingga dapat dikatakan bahwa kita memahami hukum pada masa kini dengan mempelajari sejarah. Mengingat tata hukum yang belaku sekarang mengandung anasir-anasir dari tata hukum silam dan membentuk tunas-tunas entang hukum yang akan datang.Tidak dapat dipungkiri bahwa konsekuensi logis dari studi perbandingan hukum akan membawaseorang peneliti pada sejarah hukum. Sebagaimana yang dikatakan oleh F. Pringsheim bahwa: "Comparative Law without the history of law is an impossible task"(Ibrahim, 2006)

Pendekatan perbandingan dilakukan dengan membandingkan konsep kesejahteraan dengan negara lain. Sementara Pendekatan historis dilakukan untuk mengkaji sejarah-sejarah BUMN di setiap era pemerintahan.

\section{PEMBAHASAN}

\section{Indonesia dan Konsep Negara Kesejahteraan}

Banyak ahli menyebutkan bahwa Indonesia merupakan negara yang lahir dengan konsep welfare state (negara kesejahteraan) ${ }^{3}$ terinspirasi oleh negara-negara kesejahteraan yang telah ada sebelumnya seperti negara-negara Skandinavia (Norwegia, Swedia, Denmark), meskipun penulis tidak sepenuhnya setuju dengan pendapat tersebut. Prof. Mahfud MD menyebutkan bahwa bukti Indonesia menganut negara kesejahteraan yaitu terlihat dari tujuan dan dasar negara yang tercantum di dalam Pembukaan UUD 1945. Pada bagian tujuan negara

\footnotetext{
${ }^{3}$ Welfare State (Negara Kesejahteraan) adalah konsep pemerintahan yang menitikberatkan pada peran aktif negara dalam mensejahterakan rakyatnya, negara mengambil peran penting dalam perlindungan dan pengutamaan kesejahteraan ekonomi dan sosial rakyatnya. Konsep ini didasarkan pada prinsip kesetaraan kesempatan, distribusi kekayaan yang merata dan tanggung jawab sosial bersama untuk membantu rakyat yang tidak mampu.. Contoh negara-negara yang didirikan dan dibangun dengan konsep negara kesejahteraan adalah Negara-negara Skandinavia (nordik) seperti Islandia, Swedia, Norwegia, Denmark dan Finlandia.
} 
disebutkan bahwa "negara bertujuan melindungi segenap bangsa dan seluruh tumpah darah Indonesia, mencerdaskan kehidupan bangsa, memajukan kesejahteraan umum, dan ikut melaksanakan ketertiban dunia berdasar perdamaian abadi"; sedangkan pada bagian dasar negara, Pancasila, ditegaskan di dalam sila kelima, "Keadilan sosial bagi seluruh rakyat Indonesia"4. Dalam bidang hukum administrasi konsep negara kesejahteraan melahirkan "freies ermessen" yakni berbagai kewenangan untuk melakukan langkah-langkah yang dilindungi oleh konstitusi guna membangun kesejahteraan umum.

Dalam studinya, Anderson menyebutkan bahwa welfare state merupakan institusi negara dimana kekuasaan di bidang ekonomi dan politik ditujukan untuk:

1. Memastikan setiap warga negara beserta keluarganya memperoleh pendapatan minimum sesuai dengan standar kelayakan;

2. Memberikan layanan sosial bagi setiap permasalahan yang dialami warga negara (baik dikarenakan sakit, tua atau menganggur) atau kondisi lain seperti krisis ekonomi;

3. Memastikan setiap warga negara mendapatkan hak-hak nya tanpa memandang perbedaan status, kelas ekonomi dan perbedaan lain $^{5}$.

Pendapat lain, T.H. Marshall mendefinisikan welfare state merupakan perpaduan antara demokrasi, kesejahteraan dan kapitalisme. Jika kita amati pendapat Marshall, ujung dari konsep negara kesejahteraan ini adalah pertambahan ruang kapital. Apabila kita rujuk pendapat-pendapat tersebut disimpulkan bahwa negara kesejahteraan hanya berorientasi pada kesejahteraan para warga negaranya, artinya negara akan melakukan apapun untuk mensejahterakan rakyatnya, padahal jika kita membaca tujuan negara dalam pembukaan UUD 1945 yang oleh Hans Kelsen dalam stufenbau theory dikategorikan sebagai staatsfundamentalnorm sebagaimana disinggung dalam pendapat Prof. Mahfud MD diatas bahwa negara bertujuan melindungi segenap bangsa dan seluruh tumpah darah Indonesia, mencerdaskan kehidupan bangsa, memajukan kesejahteraan umum, dan ikut melaksanakan ketertiban dunia berdasar perdamaian abadi, artinya faktor kesejahteraan bukanlah hal utama,

\footnotetext{
4 Prof. Dr.Moh. Mahfud MD, SH.,SU, BUMN sebagai Tangan Demokrasi Ekonomi untuk Kesejahteraan Rakyat, Disampaikan dalam Rakernas FSP Sinergi BUMN ke-2 di Bandung, 13 April 2016

${ }^{5}$ Dikutip dari Anderson J.G, Welfare State and Welfare State Theory, Center for Comparative Welfare Studies, Working Paper, 2012
} 
keinginan untuk lepas dari imperialisme bangsa lain yang terbukti tidak membawa kesejahteraan pada warga negara adalah tujuan utama dari Kemerdekaan Republik Indonesia.

Imperialisme yang berlangsung beratus-ratus tahun membuat seluruh sendi kehidupan berbangsa dan bernegara di Indonesia tidak bergerak, Indonesia tak ubahnya hanya sebagai objek ekslpoitasi untuk mendulang keuntungan-keuntungan politik dan ekonomi bagi negara lain. Potensi anak bangsa harus rela terkanalisasi, kecerdasan terkungkung, pendapat terbungkam, akses terhadap pendidikan dibatasi, dengan kondisi demikian mana mungkin bisa mengharapkan kesejahteraan yang luas dan merata. Kesenjangan dimana-mana, feodalisme menjadi keseharian, rakyat hidup dalam tingkatan kasta, kelas yang masing-masing kelas sosial memiliki perbedaan terhadap akses pendidikan maupun kesehatan. Keadaan tersebut menjadi latar belakang pergerakan nasional untuk memerdekaan Indonesia.

Konsep yang dirumuskan para founding parents kita lebih kepada pemusatan kekuatan untuk keluar dari belenggu imperealisme, membebaskan diri dari keterjajahan untuk menjamin segenap rakyatnya memperoleh keadilan dalam keadaban untuk bersama-sama mewujudkan kesejahteraan dan mengikis ketimpangan yang tercermin dalam 5 (lima) sila dalam Pancasila sebagai grundnorm ${ }^{6}$. Tidak benar bahwa konsep Indonesia hanya berorientasi pada pertambahan ruang kapital semata (sebagaimana definisi Marshall tentang negara kesejahteraan), jika benar demikian maka apa bedanya Indonesia dengan Amerika Serikat sebagai negara kapitalis paling sukses di dunia atau Belanda saat ini yang di cap sebagai negara paling liberal oleh beberapa pihak $^{7}$. Indonesia adalah negara berketuhanan, hal ini terlihat dari deklarasi Ketuhanan dalam Sila ke-1 Pancasila dan Pasal 29 UUD 1945, oleh karenanya sebagai negara berketuhanan Indonesia menjunjung tinggi kebenaran-kebenaran yang datangnya berasal dari Tuhan yaitu wahyu, termasuk konsep-konsep yang bersumber dari kitab suci seperti "berkah" dan "maslahat” dalam konsep pertambahan nilai.

\footnotetext{
${ }^{6}$ Grundnorm adalah norma dasar dalam sistem hukum menurut teori stufenbau yang diciptakan oleh Hans Kelsen. Stufenbau Theory menyebutkan bahwa pada dasarnya hukum itu bertingkat seperti anak tangga yang kemudian oleh kita dikenal sebagai hirarki, dimulai dari grundnorm $\rightarrow$ volkgeist $\rightarrow$ staatsfundamentalnorm $\rightarrow$ hingga hukum positif yang lebih bersifat praksis.

${ }^{7}$ Belanda saat ini sangat berbeda dengan Belanda saat menjajah Indonesia. Saat ini Belanda dinilai sebagai negara paling liberal di dunia, paling bebas, terbuka, dan sangat toleran, ini berarti bahwa sifat itu membawa negeri Belanda pada situasi dimana semua faham baru dan perilaku bisa ditoleransikan. Akibat kebebasan sekuler dan liberal telah menjadikan Amsterdam sebagai pusat peredaran obat bius bahkan ada anggota dewan kota yang pecandu narkoba, dan juga menjadi surga perilaku homoseksual, bahkan Belanda adalah negara pertama di dunia yang melegalkan euthanasia (membunuh penderita sebuah penyakit karena permohonan sendiri). Ketika Belanda menjajah Indonesia, Belanda merupakan negara yang beragama hal ini terlihat dari bangunan gereja-gereja peninggalan Belanda yang tersebar di berbagai kota di Indonesia.
} 


\section{Pancasila Sebagai Akar Filosofis BUMN}

Manisfestasi dari ideologi Pancasila terjabarkan dalam cita hukum pancasila yang berfungsi sebagai fondasi dan arah dari pembangunan dan pengembangan hukum nasional. Cita hukum pancasila dimaknai sebagai aturan tingkah laku masyarakat yang berakar pada gagasan, rasa, karsa, cipta dan pikiran dari masyarakat sendiri. Dalam hal ini terdapat tiga unsur, yakni keadilan, kehasilgunaan dan kepastian hukum ${ }^{8}$.

Para pendiri bangsa menempatkan Pancasila sebagai landasan filsafat dalam menata kerangka dan struktur dasar organisasi negara. Menurut Absori, Pancasila dimaknai sebagai pandangan hidup bangsa yang mengungkap tentang hubungan antara manusia dan Tuhan, manusia dan sesamanya dan manusia dengan alam semesta yang berintikan keyakinan tetang tempat manusia individu di dalam masyarakat dan alam semesta. Oleh karena itu perbedaan mendasar konsep ekonomi kerakyatan yang menjadi landasan pembangunan hukum ekonomi Indonesia dengan konsep negara kesejahteraan (welfare state) adalah dimensi pengungkapan hubungan manusia dengan Tuhan yang terdeklarasi dalam sila pertama Pancasila yang kemudian mengalir ke sila-sila dibawahnya.

Nilai-nilai spiritual Pancasila perlu dikembalikan untuk mencegah semakin mendominasinya pengaruh neoliberalisme dalam kebijakan-kebijakan ekonomi di Indonesia. Demokrasi bukanlah prinsip tanpa nilai spiritual, apabila kita kaji secara mendalam, nilai-nilai spiritual dalam demokrasi cukup kuat. Nilai tersebut perlu dikembalikan dengan penerapan sistem ekonomi yang berketuhanan ${ }^{9}$. Dimensi spiritual dalam Pancasila digambarkan dalam penentuan sila Pertama yang merupakan penegasan terhadap konsep tauhid deklarasi Ketuhanan (Ilahiah) yang mempercayai tidak ada Tuhan selain Tuhan Yang Maha Esa (Allah SWT), meskipun bunyi Pancasila mengalami perbedaan dengan Piagam Jakarta, namun perdebatan keduanya telah usai dan konsep tauhid disepakati menjadi sila pertama dalam Pancasila. Penentuan konsep tauhid dalam sila Pertama Pancasila menunjukkan bahwa Pancasila sebagai staatsfundamentalnorm sangat religius (Rustamaji, 2017). Pandangan Barda

\footnotetext{
${ }^{8}$ Bernard Arief Sidharta, Refleksi tentang Fundadi dan Sifat Keilmuan Ilmu Hukum sebagai Landasan Pengembangan Ilmu Hukum Nasional Indonesia, Disertasi Fakultas Hukum Universitas Padjadjaran, Bandung,1996, hal 214

${ }_{9}$ Mahkamah Konstitusi, Putusan Perkara Nomor 002/PUU-I/2003 sebagaimana diimuat dalam Berita Negara Republik Indonesia Nomor 01 Tahun 2005 terbit hari Selasa tanggal 04 Januari 2005. Hal. 208 - 209
} 
Nawawi Arief yang dikutip oleh Muhammad Rustamaji menyebutkan bahwa derivasi sila Pertama Pancasila menginspirasi tata hukum nasional menuju Biomijuridika ${ }^{10}$.

Pancasila akan mempengaruhi seluruh instrumen hukum dibawahnya, Pancasila merupakan identitas dalam sistem hukum nasional dan ideologi bangsa. Ideologi memberi kita hal-hal ideal untuk diyakini, tujuan untuk diusahakan dan alasan untuk diperjuangkan. Fungsi penting lain dari ideologi adalah membentuk identitas kelompok yang majemuk atau bangsa. Ideologi memberikan kecenderungan untuk memisahkan kita (ingroup) dan mereka (outgroup), dengan demikian Ideologi berfungsi menyatukan (Pudyastungkoro, 2010).Dalam dinamika kehidupan masyarakat Pancasila sebagai cita hukum akan berfungsi sebagai asas umum yang mempedomani, norma kritik dan faktor yang memotivasi dalam penyelenggaraan hukum (pembentukan, penemuan dan penerapan hukum) dan perilaku hukum (Absori, 2017). Dominasi positivisme mempengaruhi ketertundukan regulasi terhadap nilai-nilai dalam Pancasila, akbiatnya ruh dan semangat dalam Pancasila tidak terefleksi dalam regulasi dibawahnya, Pancasila diletakkan dalam singgasana tata aturan tertinggi yang tak mengalir pengaruhnya terhadap peraturan dibawahnya, hukum Indonesia pun menjelma tanpa identitas, liar tak terarah.

Jimly Asshiddiqie menyebutkan bahwa UUD 1945 mengandung gagasan demokrasi politik sekaligus demokrasi ekonomi. Artinya, dalam pemegang kekuasaan tertinggi di negara kita adalah rakyat, baik di bidang politik maupun di bidang ekonomi. Dalam konteks bernegara, kedaulatan rakyat bersifat relatif mutlak, meskipun harus diberi makna yang terbatas sebagai perwujudan ke-Maha-Kuasaan Allah sebagaimana diakui dalam Alinea Ketiga Pembukaan UUD 1945, sebagai konsekuensi tauhid yaitu keimanan bangsa Indonesia kepada Allah SWT, Tuhan Yang Maha Esa, maka setiap manusia Indonesia dipahami sebagai khalifah Tuhan di atas muka bumi yang diberi kekuasaan untuk mengolah dan mengelola alam kehidupan untuk sebesar-besarnya kemakmuran bersama (Asshiddiqie, 2010).

Konstitusi kita memuat tujuan-tujuan kehidupan (politik dan ekonomi) dalam bingkai transendental, mengacu pada kepercayaan akan adanya Tuhan ${ }^{11}$, demokrasi ekonomi pun bertujuan untuk menebarkan kemaslahatan. Apabila kita perhatikan, nilai dan norma dalam

\footnotetext{
${ }^{10}$ Istilah Biomijuridika dikemukakan oleh Barda Nawaw Arief untuk mencirikan suatu upaya membangun Ilmu Hukum Pidana yang tidak sekuler, yaitu Ilmu Hukum Pidana yang Berketuhanan Yang Maha Esa (Arief, 2012)

${ }^{11}$ Pancasila menempatkan nilai Ketuhanan sebagai sila Pertama, hal ini menunjukkan bahwa nilai-nilai ilahiah menjadi bingkai dalam perumusan konstitusi.
} 
konstitusi semua bertujuan untuk menciptakan maslahat, membangun kebaikan dalam komunitas negara dan kehidupan, nilai tersebut senafas dengan kandungan QS. Al Anbiya : 107

"Dan Kami tidak mengutus engkau (Muhammad) melainkan untuk (menjadi) rahmat bagi seluruh alam"

Ungkapan 'rahmat bagi seluruh alam' dalam ayat di atas bisa diartikan dengan kemasalahatan umat, meskipun makna 'rahmat' dan 'seluruh alam' terlalu luas untuk sekedar pengertian kemaslahatan manusia, karena manusia adalah salah satu komponen dari alam semesta sebagai target rahmat Allah tersebut. Dalam kaitan ini para ulama sepakat, bahwa memang hukum syara' itu mengandung kemaslahatan untuk umat manusia (Syarifuddin, 1999). Pasal 33 ayat (3) UUD 1945 menyebutkan bahwa penguasaan negara atas bumi, air dan kekayaan alam yang terkandung di dalamnya ditujukan sebesar-besarnya untuk kemakmuran rakyat, terminologi 'kemakmuran rakyat' dalam Pasal ini dapat dikaitkan dengan narasi semata-mata untuk kemaslahatan rakyat.

Al-Syatibi melihat kemaslahatan dari dua sudut pandang, yaitu (1) maqasid al-syari' (tujuan Tuhan), dan (2) maqasid al-mukallaf (tujuan mukallaf). Maqasid al-syari'ah dalam arti maqasid al-Syari', mengandung empat aspek, yaitu:

a. Tujuan awal dari syariat yakni kemaslahatan manusia di dunia dan di akhirat.

b. Syariat sebagai sesuatu yang harus dipahami.

c. Syariat sebagai suatu hukum takfif yang harus dilakukan, dan

d. Tujuan syariat adalah membawa manusia ke bawah naungan hukum (al-Syatibi, 2003)

Apabila kita kaitkan kemaslahatan dari sudut pandang Maqasid Al-Syari' menurut AlSyatibi, maka hal tersebut mengukuhkan transendensi Pancasila yang ingin mengintegrasikan sistem politik, ekonomi, hukum dan sistem bernegara secara keseluruhan ke dalam nilai-nilai Ilahiah dan melepaskan diri dari pengaruh sekularisme hukum yang dibawa oleh Penjajah selama beratus-ratus tahun dengan supremasi Ketuhanan sebagai bingkainya. 
Pancasila sebagai fondasi dan akar filosofis dari bangunan sistem berbangsa dan bernegara termasuk BUMN tidak lepas dari integrasi keilmuan dan nilai teoantroposentris, tidak semata mendasarkan kebenaran pada kecerdasan manusia, tapi menjunjung tinggi kebenaran yang berasal dari wahyu Tuhan YME, dalam konteks inilah perbedaan antara paham sekularis dan pancasilais, oleh karena itu setiap kebijakan nasional, hukum nasional dan arah gerak bangsa harus terintegrasi dengan nilai-nilai agama, meskipun tantangan deferensiasi saat ini cukup massif dan struktural, tapi itulah salah satu wujud pengingkaran (sekularisme).

Sebagai derivasi dari Sila ke-1 dalam konteks pembangunan ekonomi, BUMN harus menyadari bahwa tujuan dari BUMN tidak semata-mata untuk kepentingan kapital negara, namun harus memperhatikan aspek kemanfaatan umum (maslahat), hal ini berarti tidak ada kegiatan bisnis BUMN yang miskin manfaat dan semata-mata untuk mengejar pertambahan nilai kapital, oleh karena itu perumusan arah kebijakan ekonomi nasional dalam Pasal 33 UUD 1945 ditujukan untuk kesejahteraan kolektif dengan memaksimalkan sumber daya nasional, sehingga kebijakan eksploitasi sumber daya nasional oleh selain BUMN menjadi perdebatan dalam visi kebijakan penguasa.

\section{Sejarah BUMN}

Salah satu yang dilakukan pemerintahan Bung Karno diawal kemerdekaan adalah melakukan nasionalisasi perusahaan kolonial. Sebagaimana kita ketahui bersama bahwa Belanda pertama kali datang ke Indonesia bukan dengan pendekatan kekuatan bersenjata, melainkan dengan membawa perkumpulan usaha dagang yang dimiliki oleh Kerajaan Belanda bernama Vereenigde Oostindische Compagnie (VOC), sistem korporasi kolonial inilah yang mengeruk kekayaan alam Indonesia sehingga bangsa kita mengalami keterjajahan bertahap mulai keterjaahan secara ekonomi, sosial dan keterjajahan secara politik. Korporasi kolonial yang bertujuan semata untuk kapitalisme telah membuktikan fase keterjajahan dengan terjadinya eksploitasi besar-besaran dari kekuatan besar kepada kekuatan yang lemah, dengan segala cara termasuk dengan cara-cara memecah belah agar kepentingan ekonomi dan politiknya tercapai dengan mengenyampingkan etika, moral dan keadaban yang selama ini dijunjung tinggi masyarakat lokal. 
VOC memiliki banyak unit usaha yang mengeksploitasi kekayaan alam kita seperti Pabrik gula, kilang minyak, industri garam, kelapa sawit dan industri pendukungnya seperti perkeretaapian, stasiun radio, kantor pos dll. Setelah Indonesia merdeka Bung Karno melakukan nasionalisasi seluruh perusahaan tersebut yang kemudian bertransformasi menjadi Badan Usaha Milik Negara (BUMN) seperti PTPN, PT. Garam (Persero), PT. Pos Indonesia, Perum Percetakan Negara, PT. Kereta Api (Persero) dll. Seluruh perusahaan negara tersebut pada masa itu berada dalam kendali langsung Presiden.

Nasionalisasi perusahaan kolonial terjadi diawal kemerdekaan dimana belum ada industri swasta nasional yang bergerak di sektor industri yang dikerjakan oleh BUMN sehingga otomatis BUMN tersebut bersifat natural monopolies (memonopoli secara alamiah). Pengaruh ekonomi liberal saat itu belum terlalu besar karena keberadaan Uni Soviet sebagai kekuatan penyeimbang dunia dengan aliran ekonomi sosialis-nya. Natural monopolies BUMN ini menimbulkan kesan bahwa Indonesia cenderung pada sistem ekonomi sosialis karena sangat protektif dan belum terbuka akibat trauma akan imperealisme bangsa asing pasca penjajahan (post kolonialisme).

Saat Orde Baru Pancasila begitu dikultuskan, menjadi sumber dari segala sumber hukum. Karena pengaruh sistem hukum Eropa Kontinental yang masih sangat kental menjadikan kodifikasi hukum menjadi segala-galanya di Indonesia, sistem hukum masih mengakar pada sistem hukum kolonial yang tidak mudah begitu saja terlepas, semua organisasi diwajibkan untuk menggunakan Pancasila sebagai satu-satunya asas tunggal di negeri ini. Banyak aktivis hilang akibat keberaniannya menentang Pancasila ala Pak Harto. Kebebasan berpikir, berkumpul dan berserikat dikanalisasi untuk memudahkan penguasa memetakan persoalan yang mengancam "ideologi" versi pemerintah tersebut. Tindakan Pemerintah Orde Baru tersebut oleh Mubyarto disebut sebagai tindakan mengkotori Pancasila (Mubyarto, 2014). Orde Baru memberikan tafsiran keliru yang selanjutnya dimanfaatkan untuk kepentingan melangengkan kekuasaan atau kepentingan kelompok ekonomi penguasa, sehingga wajar jika Orde Baru bisa bertahan hingga 32 tahun.

Rezim Bung Karno tumbang seiring dengan tumbangnya rezim Stalin di Eropa Tengah, Timur dan Negara-negara Uni Soviet. Pengaruh sistem ekonomi liberal mulai terasa, hal tersebut ditandai dengan pengiriman sejumlah teknokrat ekonomi untuk menimba ilmu 
ekonomi di negara Amerika Serikat dan kembali ke tanah air untuk mengaplikasikan apa yang telah dipelajarainya (mafia Berkeley). Sistem ekonomi liberal tak terbendung, IMF, Bank Dunia mulai masuk ke Indonesia. Rezim Orde Baru merawat kapitalisme dengan memusatkan kekuatan ekonomi hanya pada kelompok konglomerat yang jumlahnya tidak lebih dari 400 keluarga (Ramli, 2014). Dalam kompetisi pasar bebas, kelompok ini akan menang karena mereka memiliki segalanya, Rizal Ramli menyebutkan bahwa orde baru banyak memberikan keistimewaan pada kelompok konglomerat ini seperti kebebasan berperilaku koruptif, kesempatan berkarir yang lebih baik serta kuota kredit yang lebih banyak pada sektor 400 konglomerat Indonesia dan BUMN. Struktur ekonomi dalam rezim ini menunjukkan bahwa Negara senang membantu kelompok yang sudah kuat, kelompok ini memiliki kebiasaan koruptif dengan menyogok dan mengkondisikan aparat negara sehingga kebijakan Pemerintah akan berpihak pada mereka.

Pada awal orde baru natural monopolies BUMN masih dibiarkan, akan tetapi kegiatan bisnis BUMN dijalankan oleh konglomerasi 400 keluarga tersebut. Pengotoran Pancasila masih terus dilakukan pemerintah orde baru, doktrinasi terhadap rakyat dilakukan sejak dini mulai dari bangku sekolah melalui penataran P4 dst, hingga pengaruh liberalisme itu sendiri yang memakan BUMN. Karena ketergantungan yang tinggi pada Amerika Serikat maka BUMN tidak cukup tangguh menopang stabilitas ekonomi bangsa yang puncaknya terjadinya krisis moneter tahun 1997. Krisis moneter tersebut mejadi awal kehancuran BUMN di era orde baru.

Pemusatan ekonomi pada BUMN menjadikan pendapatan BUMN berlimpah. Pendapatan berlimpah itu membuat pemerintah orde baru kembali menggunakan BUMN sebagai "alat" untuk mensukseskan agenda-agenda pembangunan dengan memanfaatkan dan mendistribusikan dana yang ada untuk pembangunan proyek-proyek nasional, keadaan tersebut bisa dikatakan BUMN kembali menjadi kepanjangan tangan pemerintah (semi pemerintahan) yang secara langsung dikontrol oleh Pemerintah, sehingga aktivitas BUMN cenderung merupakan aktivitas pemerintahan dan jauh dari pendekatan korporasi. Debirokratisasi BUMN melalui kontrol aktivitas bisnis dan penugasan pemerintah disatu sisi menguntungkan BUMN karena penunjukan langsung (monopoli) namun disisi yang lain menjadikan BUMN terbelenggu dengan sistem birokrasi sehingga aktivitas usaha tidak mandiri dan sangat bergantung pada pemerintah. Akibatnya BUMN tidak dilihat sebagai unit 
usaha yang mandiri dan memiliki kebebasan untuk melakukan aktivitas bisnis berdasarkan mekanisme pasar, namun BUMN kembali masuk dalam lingkaran kontrol kekuasaan politik pemerintah. Wibisono (1981) menilai era ini sama hal nya seperti era Soekarno sehingga dia menyebut sebagai era Neo-Etatisme.

Banyak permasalahan pada era tersebut, peran BUMN yang semakin kuat dalam dunia usaha nasional akibat kebijakan pemerintah menimbulkan persoalan-persoalan tersendiri seperti biaya operasional BUMN yang dinilai lebih tinggi dari sektor usaha sejenis, tidak efisien, manajemen BUMN yang kurang profesional karena sebagian besar tidak memiliki latar belakang bisnis tapi latar belakang militer, daya saing rendah hingga $\mathrm{KKN}$, sehingga timbul dorongan yang kuat dari berbagai kalangan untuk meningkatkan peran koperasi dan swasta dalam perekonomian nasional untuk mengimbangi dominasi BUMN.Pada fase ini industrialisasi belum sepenuhnya mempengaruhi struktur pengelolaan BUMN, BUMN masih dianggap sebagai kepanjangan tangan pemerintah yang harus terus dikontrol atas nama mensukseskan agenda-agenda pembangunan. Industrialisasi terjadi saat era trend minyak dunia sebagaimana diuraikan diatas, Indonesia yang memiliki kekayaan sumber minyak yang cukup besar tentu tidak ketinggalan untuk mengambil peran. Pada masa itu BUMN (Pertamina) digiring oleh pemerintah untuk mendapatkan keuntungan yang besar namun pengelolaannya tidak transparan, cenderung manipulatif dan tetap dalam kontrol pemerintah.

Perubahan keadaan terjadi secara signifikan, BUMN yang awalnya memonopoli dipaksa harus masuk dan bersaing pada pasar yang terbuka khas kapitalisme, monopoli dicabut dan ketidaksiapan infrastruktur maupun mental insan BUMN inilah menjadi awal kehancuran BUMN itu. Disaat profesionalisme BUMN berada pada titik yang terendah, BUMN masih dikuasai oleh konglomerasi penguasa, pengelolaan BUMN masih sangat koruptif dan BUMN yang biasa dimanja oleh monopoli secara tiba-tiba BUMN dipaksa masuk dalam pasar terbuka yang penuh persaingan, sungguh tindakan sistematis yang pasti hanya akan membunuh BUMN dan terbukti 142 BUMN satu demi satu berguguran karena ketidakmampuan menghadapi perubahan, masuk dalam konektifitas persaingan pasar bebas ala kapitalisme, produk mereka cenderung diproduksi dengan harga tinggi sementara kemampuan beli pasar rendah dan terdapat ketersediaan barang serupa dengan harga yang 
lebih murah akibat globalisasi yang memungkinkan produksi luar negeri masuk ke pasar Indonesia.

Setelah orde baru tumbang, pengelolaan BUMN cenderung untuk membantu pemulihan ekonomi nasional akibat krisis moneter tahun 1997 - 1998. Usaha-usaha swasta terutama yang berskala besar mengalami gangguan yang sangat serius dan sebagian besar bahkan mengalami kebangkrutan, hal itu tentu akan mempengaruhi stabilitas perekonomian nasional. Sekalipun BUMN mengalami hal yang sama, namun dalam beberapa hal BUMN masih bisa diandalkan dan menjadi tumpuan perekonomian nasional khususnya BUMN yang concern pada bisnis ekspor komoditi yang tidak terpengaruh oleh lonjakan kenaikan nilai tukar uang tapi justru diuntungkan dengan terjadinya kenaikan nilai tukar tersebut seperti BUMN sektor perkebunan.

Guna menguraikan pemahaman tentang ekonomi kerakyatan di era reformasi perlu dibagi kembali dalam fase setiap pemerintahan, sehingga dapat mengetahui secara jelas struktur hukum dan kebijakan pengelolaan BUMN setiap era pemerintahan. Pembagian tersebut, sebagai berikut:

1. Masa Pemerintahan Presiden BJ. Habibie (1998 - 2000)

Pertama kalinya dibentuk Kementerian Negara yang bertugas mengelola dan membina BUMN, dimana tugas pembinaan 177 BUMN sebelumnya melekat pada 17 Kementerian teknis masing-masing.

2. Masa Pemerintahan Presiden KH. Abdurrachman Wahid (2000 - 2001)

Pada masa pemerintahan Presiden KH. Abdurrahman Wahid, tugas pengelolaan sebagian BUMN khususnya di sektor jasa keuangan seperti perbankan, asuransi dan lembaga pembiayaan lainnya dikembalikan kepada Kementerian Keuangan dibawah Dirjend Pembinaan BUMN, sementara Kementerian Negara Pendayagunaan BUMN bertugas melakukan pembinaan BUMN selain di sektor keuangan. Kebijakan demikian untuk memperkuat kendali negara khususnya BUMN sektor keuangan dalam menopang stabilitas perekonomian nasional, sehingga aksi-aksi korporasi BUMN tidak bertentangan dengan kebijakan moneter nasional dan memperkuat perekonomian nasional.

3. Masa Pemerintahan Presiden Megawati (2001 - 2004) 
Dibentuk kembali Kementerian Negara BUMN dengan merubah nomenklatur sebelumnya yaitu Kementerian Negara Pendayagunaan BUMN, di era ini tugas pembinaan semua BUMN dikembalikan ke Kementerian Negara BUMN termasuk di sektor jasa keuangan yang sebelumnya dipegang oleh Kementerian Keuangan dibawah Dirjend Pembinaan BUMN. Pada masa ini terjadi privatisasi BUMN strategis yaitu Indosat. Privatisasi ini dinilai banyak pihak merugikan negara dan belum perlu untuk dilakukan.

4. Masa Pemerintahan Presiden Susilo Bambang Yudhoyono (2004 - 2014)

Pada masa ini pengelolaan BUMN masih dibawah Kementerian BUMN. Gelombang restrukturisasi digaungkan pada masa ini. Restrukturisasi dinilai sebagai tindakan menyelamtakan atau mengoptimalkan kinerja BUMN, tapi beberapa pihak menilai bahwa restrukturisasi ini adalah salah satu cara privatisasi BUMN. Restrukturisasi dimaksud dinamakan rightsizing yang dibagai menjadi beberapa langkah, yaitu stand alone, merger atau konsolidasi, holding, divestasi dan likuidasi.

5. Masa Pemerintahan Presiden Joko Widodo (2014 - 2018)

Pada masa ini pembinaan BUMN tetap dibawah Kementerian BUMN, program restrukturisasi melalui holding BUMN pun dilakukan seperti holidng BUMN Pupuk dibawah PT. Pupuk Indonesia, BUMN Karya, BUMN Migas, BUMN Pertambangan, BUMN Semen dll. Pada masa ini peran BUMN seolah kembali pada era orde lama (terpimpin) dan awal orde baru, dimana kontrol BUMN dilakukan secara ketat oleh Pemerintah atas nama mensukseskan agenda-agenda pembangunan nasional, sehingga banyak BUMN yang "dipaksa" untuk mengerjakan proyek yang tidak feasibel dan sebenarnya justru merugikan BUMN atas nama mengejar ketertinggalan infrastruktur nasional, seperti investasi KA cepat Jakarta - Bandung oleh 8 BUMN yang justru mengancam bisnis reguler 8 BUMN tersebut, pembangunan tol Sumatera oleh PT. Hutama Karya (Persero), pemberlakuan BBM satu harga, dll.

Pada masa ini pula terjadi politisasi BUMN secara terang-terangan dengan menempatkan para relawan dan tim sukses Presiden saat Pemilu 2014 sebagai Komisaris bahkan Direksi BUMN. Penempatan orang-orang Presiden tersebut tidak selamanya 
berkonotasi negatif, meskipun sarat kesan politis, penempatan orang kepercayaan Presiden mungkin untuk memastikan pengelolaan BUMN dilakukan dengan baik, sesuai dengan visi dan misi Presiden dalam pembanganunan di sektor ekonomi, sehingga arah gerak BUMN terintegrasi dengan kebijakan ekonomi Presiden.

\section{BUMN Instrumen Ekonomi Kerakyatan}

Bung Hatta, salah satu founding parrents Indonesia menyebutkan kesejahteraan bersama dapat diwujudkan dengan penguatan koperasi dan Badan Usaha Milik Negara (BUMN) sebagai soko guru ekonomi nasional. Sebagai perumus Pasal 33 UUD 1945, sudah barang tentu arah sistem ekonomi kita sangat jauh dari konsep kapitalisme sebagaimana dianut oleh negara-negara barat. Dalam konsep Hatta, sektor ekonomi sebisa mungkin digerakkan oleh kaki tangan sendiri (koperasi dan BUMN).

Kehadiran BUMN menunjukkan gagasan dan arah kebijakan ekonomi nasional. Konstitusi telah menggariskan konsep ekonomi kerakyatan sebagai landasan ideologi ekonomi, hal tersebut terlihat dari arah kebijakan ekonomi yang tercantum dalam Pasal 33 UUD $1945^{12}$. Dalam UUD 1945 Amandemen ke-4 terminologi ekonomi kerakyatan dirubah istilahnya dengan demokrasi ekonomi, sistem ekonomi yang mengedepankan prinsip kebersamaan, efisiensi berkeadilan, berkelanjutan, berwawasan lingkungan, kemandirian serta dengan menjaga keseimbangan kemajuan dan kesatuan ekonomi nasional ${ }^{13}$. Konstitusi ekonomi dengan mendasarkan pada demokrasi ekonomi adalah sistem ekonomi jalan tengah, tidak liberal yang berorientasi pada kapitalistik dan tidak sosialis, tapi sistem ekonomi yang berakar pada Pancasila, ciri khas bangsa Indonesia.

BUMN adalah instrumen ekonomi kerakyatan, karena konsep BUMN merupakan konsep pemerataan dengan menghindari pemusatan kekuatan ekonomi pada kelompokkelompok tertentu, sehingga kesejahteraan yang akan diraih ditujukan bagi kesejahteraan kolektif, jelas bahwa inilah ruh dari ekonomi kerakyatan. BUMN merupakan implementasi Pasal 33 UUD 1945 yaitu penguasaan cabang-cabang produksi yang penting bagi negara dan

\footnotetext{
${ }^{12}$ Pasal 33 UUD 1945 oleh Prof. Jimly Asshiddiqie disebut sebagai konstitusi ekonomi. Konstitusi ekonomi berarti pijakan hukum tertinggi dalam bidang ekonomi. Selama ini kita mengenal konstitusi sebagai pijakan di bidang politik semata, karena beberapa ahli hukum mengkategorisasikan hukum ekonomi tidak berdiri sendiri melainkan digolongkan dalam kategori hukum publik bersama rumpun hukum perdata dan hukum dagang, meskipun perumpunan ini dikritik sebagai ketidakmampuan sistem hukum nasional untuk lepas dari pengaruh hukum Belanda.

${ }^{13}$ Pasal 33 ayat (4) UUD 1945 menyebutkan bahwa Perekonomian Nasional diselenggarakan berdasar atas demokrasi ekonomi dengan prinsip kebersamaan, efisiensi berkeadilan, berkelanjutan, berwawasan lingkungan, kemandirian serta dengan menjaga keseimbangan kemajuan dan kesatuan ekonomi nasional
} 
menyangkut hajat hidup orang banyak, artinya ketika sektor produksi dinyatakan sebagai sektor produksi yang memenuhi unsur 1) penting dan 2) menguasai hajat hidup orang banyak, maka harus diselenggarakan oleh BUMN, tidak boleh oleh swasta, perorangan apalagi asing. BUMN tentu tidak disukai oleh para kapitalis yang berjuang sedemikian rupa untuk kepentingan ekonominya.

Prof. Dr. Jimly Asshiddiqie, SH berpendapat bahwa sasaran dari sistem ekonomi kerakyatan adalah pembebasan kehidupan rakyat dari kemiskinan, kebodohan, ketergantungan, perlakuan tidak adil, kerusakan lingkungan dan rasa was-was dalam menatap masa depan (Asshiddiqie, 2010). Karena itu kebijakan ekonomi nasional seharusnya tidak keluar dari asas ekonomi kerakyatan yang menurut Soeharsono Sagir tercermin dalam prinsip triple track development, yaitu pro-poor, pro-job dan pro-growth(Sagir, 2009). Salah satu upaya mewujudkan kesejahteraan itu dengan industrialisasi, meskipun kita dihadapkan pada tantangan hegemoni dunia oleh industrialisasi yang saat ini telah terbagi dalam 4 era (4.0) dengan masing-masing era nya menitikberatkan pada ke khas-an tersendiri sebagaimana telah diuraikan diawal tulisan diatas.

\section{BUMN di Era Revolusi Industri 4.0}

Revolusi industri pertama yang terjadi di Britania Raya dan menyebar ke Eropa barat hingga ke seluruh dunia termasuk Indonesia tentu membawa dampak perubahan tersendiri. Revolusi Industri merubah Inggris menjadi negara industri yang maju dan modern. Di Inggris muncul pusat-pusat industri, seperti Lancashire, Manchester, Liverpool, dan Birmingham. Seperti halnya revolusi yang lain, Revolusi Industri juga membawa akibat yang lebih luas dalam bidang ekonomi, sosial dan politik, baik di negeri Inggris sendiri maupun di negaranegara lain termasuk di Indonesia. Dampak revolusi industri bagi Indonesia telah dirasakan sejak jaman kolonialisme yaitu dengan diwajibkannya rakyat untuk bekerja rodi membangun infrastruktur, tanam paksa hanya untuk kepentingan industrialisasi Belanda.

Seiring dengan kemerdekaan yang berhasil diraih, terjadi nasionalisasi terhadap seluruh infrastruktur bisnis yang dimiliki pemerintah Hindia Belanda dan di tranformasikan menjadi Badan Usaha Milik Negara (BUMN). Era Revolusi Industri tidak berdampak signifikan bagi seluruh BUMN, hanya BUMN tertentu yang harus menyesuaikan layanannya 
melalui transformasi teknologi untuk meningkatkan nilai tambah bagi BUMN, karena sejatinya revolusi industri hanya bekerja untuk menambah ruang kapital, sehingga penting bagi BUMN di sektor perbankan, telekomunikasi, listrik, energi dan jasa penerbangan yang layanannya langsung menyentuh masyarakat. Disisi yang lain, birokratisasi BUMN masih menjadi kendala dalam upaya modernisasi BUMN. Birokrasi kita yang dianggap masih konvensional tidak bisa diintegrasikan dengan program korporatisasi BUMN, hal ini terlihat dari masih adanya Kementerian BUMN sebagai induk koordinasi dari BUMN-BUMN bahkan secara regulasi dinyatakan sebagai RUPS ${ }^{14}$

Tantangan bagi BUMN kita di era industri ini adalah menyederhanakan seluruh proses birokratisasi di Kementerian BUMN khususnya dalam pengambilan keputusan-keputusan strategis yang memerlukan persetujuan Kementerian BUMN sebagai wakil negara selaku pemilik modal. Adalah sebuah keniscayaan perwujudan super holding BUMN untuk menjawab tantangan-tantangan di era digitalisasi dan financial technology (fintech) agar BUMN kita bisa lebih fleksibel dan dinamis dengan melepaskan belenggu aturan-aturan yang selama ini menjadi penghalang proses modernisasi BUMN sementara BUMN dihadapkan pada perubahan perilaku masyarakat menjadi masyarakat digital, sehingga layanan-layanan digital pun perlu dipersiapkan dengan baik.

Harus diakui bahwa BUMN hari ini terbawa dalam pusaran arus industrialisasi global yang bekerja menyuburkan kapitalisme, hal itu menyebabkan aspek-aspek ekonomi menjadi pertimbangan utama dibandingkan aspek-aspek lain seperti sosial, budaya dan lingkungan. Sebagaimana telah dielaborasi dalam artikel diatas bahwa kapitalisme merupakan produk yang berasal dari filsafat modern dan rasionalisme sehingga kapitalisme pun menempatkan kecerdasan manusia sebagai sumber kebenaran utama, mengenyampingkan moral dan etis yang berdampak pada saling bunuh dalam persaingan bisnis, kapitalisasi pelayanan umum dan tentunya korupsi, kolusi dan nepotisme yang ujung-ujungnya adalah ketimpangan. Hal tersebut tentu tak ada bedanya dengan era sebelum kemerdekaan dimana rakyat Indonesia hidup dalam ketimpangan ekonomi dan jauh dari kesejahteraan kolektif.

\footnotetext{
${ }^{14}$ Tanri Abeng, Menteri BUMN pertama yang saat itu bernama Menteri Pendayagunaan BUMN memandang idealnya Kementerian BUMN hanya berdiri paling lama 4 tahun untuk mempersiapkan proses korporatisasi BUMN dalam grand design mengembalikan BUMN sebagai korporasi murni dan memisahkan dengan hubungan-hubungan birokrasi yang cenderung kotor dan berbelit-belit. Hal ini cukup penting karena BUMN tidak hanya dipersiapkan untuk persaingan lokal dengan non BUMN industri sejenis semata tapi dihadapkan pada kompleksitas persaingan global yang melibatkan dimensi negara sebagai pelakunya.
} 


\section{Kritik Terhadap Basis Berpikir Era Revolusi Industri}

Pengaruh hegemoni barat dengan aliran pemikiran filsafat liberalisme tumbuh begitu subur di Indonesia, tidak sedikit para ahli yang mendapat pendidikan di barat kembali ke tanah air sebagai penyubur aliran pemikiran filsafat liberalisme ini. Liberalisme merupakan aliran pemikiran modern yang tumbuh dalam bingkai kapitalisme. Modernisme menghasilkan masyarakat yang bebas tak terbatas, bebas nilai, mengangungkan rasionalitas dan kebenaran empirik, mengaburkan batas-batas etis, bermuara pada materialisme yang hanya menyisakan persoalan yang tidak dapat dijawab oleh pendekatan yang sama.

Aliran filsafat liberalisme menghasilkan sistem ekonomi liberal, sistem ekonomi yang membuat siapa yang kuat maka dia yang akan berkuasa, ciri khas negara kapitalis seperti Amerika. Amerika memang tidak pernah menjajah Indonesia secara fisik, namun Indonesia dengan masyarakatnya yang sangat heterogen dan ideologi terbuka menjadi potensi pengaruh tersebut berkembang cukup pesat. Doktrin tersebut memiliki daya pengaruh yang sangat kuat pasca jatuhnya rezim Stalin di Eropa Tengah dan Timur serta Negara-negara bekas Uni Soviet. Keberagaman dan keterbukaan terhadap pemikiran luar puncaknya terjadi setelah reformasi. Pada saat Orde Baru Pemerintah berusaha untuk menyeragamkan pemikiran dan ideologi, dan usaha itu bisa dikatakan berhasil, pada masa reformasi menjadi pintu gerbang berbagai arus pemikiran datang dan berkembang di Indonesia, kebebasan berpikir, berserikat dan berkumpul diterjemahkan secara liar bahwa setiap pemikiran barat mendapat tempat untuk di aplikasikan di Indonesia, al hasil terjadilah keadaan yang kita jalani hari ini.

Demokrasi diartikan secara bebas yang akhirnya berujung pada demokrasi berbiaya tinggi (high cost democrazy) yang menyebabkan terjadinya perselingkuhan antara kekuasaan politik dengan kekuatan ekonomi tertentu. Hukum dan kebijakan sebagai produk politik akhirnya dijadikan agunan untuk memperoleh bantuan pembiayaan dari kekuatan-kekuatan ekonomi karena dalam proses sirkulasi kepemimpinan nasional dalam demokrasi di Indonesia memerlukan biaya yang sangat tinggi dan kebutuhan pembiayaan politik tersebut dipenuhi dari para investor politik yang berharap kepentingan ekonominya bisa terakomodasi dalam hukum dan kebijakan saat calon pemimpin yang tengah berkontestasi terpilih. 
Kualitas dan kapasitas pemimpin bukanlah segala-galanya, faktor baru yang mempengaruhi tingkat keterpilihan (elektabilitas) calon pemimpin adalah ketersediaan sokongan investor dalam pembiayaan proses pemilihan, mulai dari biaya perahu (biaya yang dibutuhkan untuk mendapatkan dukungan dari partai politik), biaya kampanye hingga biaya yang dibutuhkan untuk serangan fajar (money politic) itulah relaitasnya. Sistem pemilu saat ini yang berbiaya tinggi kemudian menjadi pintu masuk terjadinya liberalisasi yang berdampak pada kualitas pemimpin yang dihasilkan dan degradasi nilai dari demokrasi itu sendiri.

Keadaan ini disebabkan karena sistem membiarkan (cenderung menyuburkan) terjadinya diferensiasi nilai-nilai pemikiran yang berangkat dari mengagungkan kecerdasan manusia sebagai satu-satunya sumber kebenaran dan menempatkan sumber kebenaran lain yang berasal dari Tuhan (wahyu) dalam kotak pandora. Kebenaran dari Tuhan hanya sekedar diakui tapi tidak diimplementasikan, hal ini dikarenakan kesalahan nalar berpikir manusia modern yang menurut Kuntowijoyo berasal dari filsafat rasionalisme memandang manusia sebagai spesies paling utama di muka bumi sehingga menghasilkan kebenaran hanya pada sudut pandang ekslusifis manusia (antroposentris) yang mengakibatkan terjadinya deferensiasi yaitu pembedaan antara urusan-urusan yang bersifat duniawi dengan urusanurusan yang bersifat $u k h r a w i$ / agamawi sehingga berkembanglah ilmu-ilmu sekuler ${ }^{15}$.

Konsep revolusi Industri berangkat dari kebutuhan manusia yang dipenuhi oleh ilmuilmu sekuler karena berakar pada filsafat rasionalisme yang menganggap sumber kebenaran utama adalah kebenaran yang berasal dari kecerdasan manusia, sehingga seluruh tahapan revolusi industri 1.0 sampai dengan 4.0 menitikberatkan pada pemampatan ruang dan waktu melalui inovasi dari kecerdasan manusia dengan tujuan utama hanya untuk penambahan nilai (kapitalisme). Rasionalisme bekerja untuk kapitalisme dan sebagaimana diketahui bahwa kapitalisme akan menciptakan ruang eksploitasi kekuatan kecil oleh kekuatan-kekuatan besar dan mengenyampingkan nilai-nilai etis dan moral yang dibawa oleh agama, sehingga di era revolusi industri 4.0 ini kita akan mudah melihat kejadian-kejadian unethical dan amoral yang diproduksi oleh masyarakat industri di dunia, sebut saja industri pornografi, sex toys, robot untuk pemenuhan kebutuhan seksual, media sosial yang tidak terkontrol, caci maki menjamur,

\footnotetext{
${ }^{15}$ Kuntowijoyo, Islam sebagai Ilmu ; Epistemologi, Metodologi dan Etika, Ujung Berung, Bandung : Teraju, 2004
} 
ujaran kebencian dimana-mana, penyebaran hoax dan fitnah yang meraja lela melalui media sosial yang sering miskin substansi.

\section{PENUTUP}

Hegemoni industrialisasi yang berkiblat pada pemikiran barat (filsafat modern) secara nyata dirasakan dampaknya di Indonesia. Industrialisasi yang dibangun bekerja untuk meningkatkan nilai pada ruang-ruang kapital, bahayanya kita menerima arus pemikiran tersebut atas nama kebebasan berpikir, meskipun pemikiran yang dibangun adalah pemikiran bebas nilai (value free) termasuk nilai moral dan etis. Revolusi industri telah menjadi kelatahan nasional, bangsa ini sibuk untuk mempersiapkan akselerasi terhadap arus baru, bukan memikirkan bagaimana melawan arus baru tersebut demi mempertahankan bangunan bangsa yang berketuhanan dengan mengedepankan nilai moral dan etis sebagaimana diamanahkan dalam Pancasila.

Kesadaran kita yang terlambat terhadap invasi barat melalui pemikiran modern yang kering dan bebas nilai membuat masyarakat Indonesia manut pada keterpaksaan digitalisasi masyarakat yang hanya menjerumuskan, akibatnya terjadi banyak pelanggaran norma dan etis dalam masyarakat digital seperti kejahatan dalam e-commerce, menjadikan media sosial sebagai fasilitas terjadinya kejahatan-kejahatan yang berawal dari dunia maya, penyalahgunaan kewenangan, KKN semakin merebak bahkan lebih maju menyesuaikan dengan perkembangan teknologi informasi, penggunaan sandi-sandi digital, termasuk BUMN. BUMN kita masih sibuk bersih-bersih diri, KKN susah dilepaskan, BUMN tak ubahnya menjadi alat kapitalisasi negara, menghancurkan pelaku usaha kecil yang akhirnya rakyat menjadi korban kembali.

BUMN seharusnya mulai mempersiapkan diri untuk lepas landas, mempersembahkan kinerja terbaik dengan membawa nilai-nilai nasional dalam kontestasi internasional, betulbetul menjadi soko guru ekonomi bangsa dengan pemaksimalan pengelolaan sumber daya nasional yang dikelola dengan profesional, efektif, efisien, akuntabel, transparan dan mengedepankan kepentingan nasional dengan tetap memegang tegun falsafah ekonomi Pancasila yang berorientasi pada kesejahteraan kolektif, tidak liberal, tidak sosialis tapi bersendikan nilai-nilai Ketuhanan yang mengutamakan tingkat maslahat (kemanfaatan) dan 
nilai berkah (kebaikan yang terus-menerus dan berkesinambungan), sehingga kesenjangan ekonomi, sosial akan terkikis, keadilan dan kemakmuran menjadi nyata.

\section{REFERENCES}

Absori, 2017. Pemikiran Hukum Transendental dalam Konteks Pengembangan Ilmu Hukum Indonesia. Transendensi Hukum Prospek dan Implementasi, p. 14.

al-Syatibi, A. I., 2003. Al-Muwafaqat fi Usủl al-Syari’ah. Cet III ed. Bayrut: Dar Kutub al'Ilmiyyah.

Asshiddiqie, J., 2010. Konstitusi Ekonomi. Jakarta: Kompas Gramedia.

Anderson J.G, 2012, Welfare State and Welfare State Theory, Center for Comparative Welfare Studies, Working Paper

Bernard Arief Sidharta, 1996, Refleksi tentang Fundadi dan Sifat Keilmuan Ilmu Hukum sebagai Landasan Pengembangan Ilmu Hukum Nasional Indonesia, Bandung, Disertasi Fakultas Hukum Universitas Padjadjaran

Johnny Ibrahim. 2006. Teori dan Metodologi Penelitian HukumNormatif. Malang: Bayumedia Publishing.

Mubyarto, 2014. Ekonomi Kerakyatan Dalam Era Globalisasi. Jakarta: Lembaga Suluh Nusantara bekerjasama dengan American Institute for Indonesian Studies.

Mahfud MD, 2016, BUMN sebagai Tangan Demokrasi Ekonomi untuk Kesejahteraan Rakyat, Disampaikan dalam Rakernas FSP Sinergi BUMN ke-2 di Bandung, 13 April 2016

Pudyastungkoro, D., 2010. Wawasan Kebangsaan, Pancasila dan Persatuan Bangsa. Jakarta: Kompas Gramedia.

Ramli, R., 2014. Telaah Wacana Ekonomi Kerakyatan. Jakarta: Lembaga Suluh Nusantara.

Rustamaji, M., 2017. Menggali Akar Transendensi Pancasila Menuju Ilmu Hukum Berketuhanan Yang Maha Esa. p. 384.

Sagir, S., 2009. Kapita Selekta Ekonomi Indonesia. Jakarta: Prenada Media Group.

Syarifuddin, A., 1999. Fiqh, Ushul. Cetakan I ed. Jakarta: PT. Logos Wacana Ilmu. 